\title{
The Assessment of Anatomic Structure of Median Nerve in Diabetic and Control Group Patients Using Ultrasound: A Controlled Study
}

\section{Esra ÇiRCí1 id, Sibel ÇAĞLAR OKUR² id}

${ }^{1}$ Clinic of Orthopedics and Traumatology, İstanbul Training and Research Hospital, İstanbul, Turkey

${ }^{2}$ Clinic of Physical Medicine and Rehabilitation, Bakırköy Training and Research Hospital, İstanbul, Turkey

\section{ABSTRACT}

Objective: In this study we measured the anatomic structure of median nerve in three different levels of carpal tunnel in diabetic and control group patients using ultrasound.

Methods: Between January 2016 and May 2016, 52 diabetic and 46 control group patients were evaluated by ultrasound. Median nerve cross sectional area was measured and recorded in its largest part at the level of proximal, midtunnel, and distal of transvers carpal ligament.

Results: While no significant difference was found between the measurement of the median nerve cross sectional area at proximal level $(\mathrm{p}>0.05)$, a significant differences was found in the midtunnel and distal level of transvers carpal ligament $(\mathrm{p}<0.05)$. Median nerve cross sectional area was found to be larger in the diabetic patients than in control group patients.

Conclusion: The anatomical structure of median nerve can be dynamically evaluated in a short time without causing any discomfort to the patient using ultrasound. Ultrasound is a valuable imaging technique tp detect changes occurring at an early stage in median nerve in patients with risk of peripheral neuropathy.

Keywords: Diabetes, median nerve, ultrasound

\section{Introduction}

Diabetes is a chronic and progressive disease, characterized by hyperglycemia. It progresses with impaired carbohydrate and lipid metabolism. Insufficient insulin secretion causing the usage of impaired carbohydrate metabolism is a characteristic feature of diabetes. In the presence of chronic hyperglycemia in the neurons and Schwann cells, glucose is converted into glucose-6-phosphate by hexokinase. This results in a change in the osmotic permeability, which leads to swelling in the axon and nerve roots. Prolonged hyperglycemia increases oxidative stress (1). In patients with diabetes, glucolization of structural proteins (e.g., type IV collagen, laminin) causes abnormal cross-linking of these proteins, impairs their functions, and makes them durable to degradation. With the glucolization of collagenase enzyme, the function of collagen degradation is impaired, and collagen is accumulated in the tissue where it causes damage (2). It has been hypothesized that swelling develops in the fluid content of peripheral nerves due to an increase in the levels of aldose reductase enzyme, which converts glucose to sorbitol in patients with diabetes (3). It has been determined that impaired glucose tolerance and progressive insulin insufficiency affect neuropeptide synthesis even in the absence of hyperglycemia, and that these are associated with functional and structural neuropathy (1).

Carpal tunnel syndrome is the most common entrapment neuropathy that develops due to the compression of the median nerve in the wrist beneath the transverse carpal ligament while passing through the carpal tunnel. Thickened transverse carpal ligament or increased pressure due to edema in the tunnel is a cause of carpal tunnel syndrome. This syndrome is characterized by pain in the hand and wrist and numbness and paresthesia in the distribution area of the median nerve (4).

Cite this article as: Çirci E, Çağlar Okur S. The Assessment of Anatomic Structure of Median Nerve in Diabetic and Control Group Patients Using Ultrasound: A Controlled Study. Bezmialem Science 2018; 6:27-30.

\begin{tabular}{|c|c|}
\hline $\begin{array}{l}\text { Address for Correspondence: Esra ÇíRCi, İstanbul Eğitim ve Araştırma Hastanesi, Ortopedi ve Travmatoloji Kliniği, } \\
\text { İstanbul, Türkiye E-mail: esracirci@hotmail.com }\end{array}$ & $\begin{array}{l}\text { Received } \\
\text { Accepted }\end{array}$ \\
\hline
\end{tabular}


Ultrasonography of the median nerve anatomy in the hand allows the early diagnosis of pathologies $(4,5)$. In this study, we aimed to examine the anatomical structure of the median nerve using noninvasive ultrasound technique in patients with diabetes and control individuals and to compare the patients at risk for entrapment neuropathy with control individuals.

\section{Methods}

For the study, ethical committee approval was received from Bakırköy Education and Research Hospital (2018/113), and informed consent was obtained from the patients who participated in the study. In İstanbul Education and Research Hospital between January 2016 and May 2016, the median nerve of the right hand was evaluated through ultrasonography from three different regions of the carpal tunnel in 98 patients, including 52 with diabetes and 46 controls. All patients in the diabetic and control groups were dominantly right-handed. Patients aged $<18$ years were excluded from the study. Moreover, patients diagnosed with rheumatoid arthritis or any neuropathic disease were also excluded.

\section{Study group}

A total of 52 patients with diabetes (20 male and 32 female) who were followed up for the diagnosis of type II diabetes and whose mean age was $62.4 \pm 9.6$ years were evaluated. The mean duration of follow-up for the diagnosis of diabetes was $10.3 \pm 7.5$ years. Durations of diabetes and treatment were recorded. Patients with clinical findings of entrapment neuropathy (e.g., numbness, tingling, and electrical sensations) were not included in the evaluation. Tinel's and Phalen's tests were performed, and the patients who did not display any findings were included in the study. Body mass indices (BMIs) of all patients were calculated. As laboratory parameter, HbAlc levels in all patients were measured.

\section{Control group}

A total of 46 patients with no history of diabetes (20 male and 26 female) who were admitted to our hospital for other examinations, who did not have any problem on their hands, and whose mean age was $66,2 \pm 7,8$ years were evaluated. Patients having the clinical symptoms of entrapment neuropathy such as numbness, tingling, and electrical sensation on the hands were not evaluated. Tinel's and Phalen's tests were used, and the patients without any findings were included in the study. Furthermore, in the control group, HbA1c levels were measured and BMIs were calculated.

\section{Ultrasonographic evaluation}

With the patients in the supine position, neutrally positioned hands were evaluated using ultrasound. For the ultrasound examination, a linear probe (Esaote MyLab 5; Genova, Italy) in the $5-13-\mathrm{MHz}$ frequency range was used. The evaluation was performed by a specialist experienced in the musculoskeletal system.

The localization of the median nerve was determined through dynamic examination in the axial plane during flexion and extension movements of the fingers by benefiting from the flexor tendons of the second and third fingers. A hypoechoic fibrillar formation was found between the flexor tendons of the first three fingers beneath the flexor retinaculum. With the help of ultrasonography, the cross-sectional area of the median nerve was measured in the proximal and distal regions of the transverse carpal ligament as well as under the ligament. After determining the ovoid margins of the median nerve on ultrasonography, three measurements were performed, and the average value was calculated. In the ultrasonography device, the axial sectional area was determined with Tr-Area measurement.

\section{Statistical analysis}

Statistical analysis was performed with the Statistical Package for the Social Sciences (SPSS Inc.; version 17.0, Chicago, IL, USA) software. A p value of $<0.5$ was considered statistically significant. The data were presented as the mean \pm standard deviation. The independent sample t-test was used for the comparison of differences in age, BMI, HbAlc level, and cross-sectional area of the median nerve in the diabetic and control groups.

\section{Results}

The mean BMI was found to be $29.6 \pm 4.2 \mathrm{~kg} / \mathrm{m}^{2}$ in the diabetic group and $33.6 \pm 4.6 \mathrm{~kg} / \mathrm{m}^{2}$ in the control group. The mean $\mathrm{HbAlc}$ value was $8.0 \% \pm 1.7 \%$ in the diabetic group and $5.7 \% \pm 0.2 \%$ in the control group. Demographic distributions of the data are shown in Table 1.

No significant difference in terms of age, gender, and BMI ( $p>0.05$ ) was detected between the diabetic and control groups. However, there was a significant difference between the groups with regard to HbA1c levels $(\mathrm{p}<0.05)$.

In the group of patients with diabetes, the average cross-sectional area of the median nerve was measured as $10.2 \pm 2.9$ $\mathrm{mm}^{2}$ in the proximal region, $7.5 \pm 1.9 \mathrm{~mm}^{2}$ beneath, and $7.7 \pm 1.8 \mathrm{~mm}^{2}$ in the distal region of the transverse carpal ligament. In the control group, the average cross-sectional area of the median nerve was $10.2 \pm 2.5 \mathrm{~mm}^{2}$ in the proximal region, $6.9 \pm 1.3 \mathrm{~mm}^{2}$ beneath, and $6.6 \pm 1.4 \mathrm{~mm}^{2}$ in the distal region of the transverse carpal ligament.

\section{Table 1. Demographic distributions of data}

\begin{tabular}{|c|c|c|c|}
\hline & $\begin{array}{c}\text { Diabetic } \\
\text { group } \\
\text { patients }\end{array}$ & $\begin{array}{c}\text { Control } \\
\text { group } \\
\text { patients }\end{array}$ & $\begin{array}{c}\text { Statistical } \\
\text { evaluation* }\end{array}$ \\
\hline BMI $\left(\mathrm{kg} / \mathrm{m}^{2}\right)$ & $29.6 \pm 4.2$ & $33.6 \pm 4.6$ & $p>0.05$ \\
\hline HgA1c (\%) & $8.0 \pm 1.7$ & $5.7 \pm 0.2$ & $p<0.05$ \\
\hline Age (year) & $62.4 \pm 9.6$ & $66.2 \pm 7.8$ & $p>0.05$ \\
\hline Gender (female/male) & $32 / 20$ & $26 / 20$ & $p>0.05$ \\
\hline
\end{tabular}


Table 2. Data on the evaluation of the cross sectional area (mm2) of the median nerve through ultrasonography

\begin{tabular}{|c|c|c|c|}
\hline & $\begin{array}{c}\text { Diabetic } \\
\text { group } \\
\text { patients }\end{array}$ & $\begin{array}{c}\text { Control } \\
\text { group } \\
\text { patients }\end{array}$ & $\begin{array}{c}\text { Statistical } \\
\text { evaluation* }\end{array}$ \\
\hline $\begin{array}{l}\text { In the proximal region of the } \\
\text { transverse carpal ligament }\end{array}$ & $10,2 \pm 2,9$ & $10,2 \pm 2,5$ & $p>0,05$ \\
\hline $\begin{array}{l}\text { Beneath the transverse } \\
\text { carpal ligament }\end{array}$ & $7,5 \pm 1,9$ & $6,9 \pm 1,3$ & $p<0,05$ \\
\hline $\begin{array}{l}\text { In the distal region of the } \\
\text { transverse carpal ligament }\end{array}$ & $7,7 \pm 1,8$ & $6,6 \pm 1,4$ & $p<0,05$ \\
\hline
\end{tabular}

While the cross-sectional area of the median nerve was not significantly different in the proximal region of the transverse carpal ligament $(p>0.05)$ between the diabetic and control groups, it was significantly different beneath and in the distal region of the transverse carpal ligament $(\mathrm{p}<0.05)$. The crosssectional area of the median nerve was more in the diabetic group. The ultrasonographic evaluation data of the cross-sectional area of the median nerve are summarized in Table 2.

\section{Discussion}

Diabetes is a chronic and progressive disease that causes damage in many tissues. Its most common complications include flexor tenosynovitis, Dupuytren's contracture, stiffness in the hands, entrapment neuropathy, and infections (6).

Carpal tunnel syndrome is the most common entrapment neuropathy. It can be idiopathic or caused by many factors (7). One of the important causes of the predisposing factors is diabetes (8). The incidence of carpal tunnel syndrome in patients with diabetes has been reported to be $15 \%-33 \%$ ( 9 , $10)$.

In the ultrasonographic evaluation of the carpal tunnel anatomy, it was observed that the bone and ligamentous walls of the carpal tunnel and soft tissues inside it could be better examined axially. The median nerve extends just below the flexor retinaculum and between the muscles of the flexor pollicis longus and superficial digital flexor muscles. Axially, it appears as an ovoid fibrillary structure, the long axis of which is parallel to the flexor retinaculum. When the scanning angle of ultrasonography is vertical to the nerve, it appears hyperechoic; when the angle is oblique, it appears hypoechoic. Longitudinally, the median nerve is observed as a fibrillary structure shaped as a band extending above the flexor tendons (11).

When radiological methods were investigated, it was observed that ultrasonography is used in the evaluation of the musculoskeletal system and soft tissues. The use of high-frequency linear probes with ultrasound has facilitated the imaging of the peripheral nerves to a great extent $(4,5,12)$.
Different results have been obtained in studies that aimed to determine the normal values of the cross-sectional area of the median nerve. In 1999, Duncan et al. (13) performed a study on 68 patients with carpal tunnel syndrome and 39 controls and stated that the cross-sectional area of the median nerve of $>9 \mathrm{~mm}^{2}$ measured at the scaphoid-pisiform level is the optimal sonographic evaluation criterion in the ultrasonographic assessment for the diagnosis of carpal tunnel syndrome. In the study of Nakamichi et al. (14) in 2002 conducted on 275 patients with carpal tunnel syndrome and 408 healthy individuals, the median nerve diameter of $12 \mathrm{~mm}^{2}$ was calculated with $67 \%$ sensitivity and $97 \%$ specificity in the ultrasonographic diagnosis of carpal tunnel syndrome considering the measurement values obtained from three different levels in the wrist covering the proximal, lower, and distal regions of the carpal tunnel. In the study of Yeşildağ et al. (15), 68 patients with carpal tunnel syndrome and 45 asymptomatic individuals were evaluated. The authors demonstrated that the diagnosis of carpal tunnel syndrome could be established with $89 \%$ sensitivity and $97 \%$ specificity when the threshold value for the cross-sectional area of the median nerve was $>10.5 \mathrm{~mm}^{2}$ at the entry level. Thus, in ultrasonographic evaluations, the dilatation of the median nerve at the level of the proximal carpal tunnel has been reported to be the most commonly used criterion for the diagnosis of carpal tunnel syndrome. However, in many studies (16-18), different threshold levels have been reported for the increase in the nerve diameter. In our study, while the cross-sectional area of the median nerve did not differ in the proximal region of the transverse carpal ligament between the groups, it was higher beneath and in the distal region of the transverse carpal ligament in the diabetic group than in the control group. The increase in the median nerve diameter in patients with diabetes was lower than the threshold value reported for carpal tunnel syndrome in the literature. In conclusion, compared with the control group, increased median nerve diameter was detected in patients with diabetes without clinical symptoms of entrapment neuropathy and clinical findings of carpal tunnel syndrome.

This condition in patients with diabetes can be explained by the presence of swelling in the axon and nerve roots due to increased osmotic permeability. Moreover, an increase in aldose reductase enzyme activity, which enables the conversion of glucose into sorbitol, is observed in patients with diabetes, which may also cause swelling as well as an increase in the fluid content of the peripheral nerves. We believed that the detection of increased median nerve diameter in patients with diabetes without clinical findings may be associated with pathophysiological mechanisms underlying diabetes. We recommend the evaluation of the nerve diameter from three different levels as in the study of Nakamichi et al. (14) instead of a single level as in the study of Duncan et al. (13).

In our study, Tinel's and Phalen's provocative tests were performed. Patients without the findings of entrapment neuropathy in the provocative tests were included in the study. 
Our aim was to provide early diagnosis of diabetes-associated peripheral neuropathy before the occurrence of its clinical findings. The patients in our study were noninvasively evaluated using ultrasonography. Regarding the electrophysiological tests, electromyography was not performed to evaluate the patients, which is a limitation of our study.

\section{Conclusion}

Ultrasonography enables dynamic evaluation of the anatomical structure of the median nerve with a high image quality and without disturbance to the patient. In this controlled study, an increase in the median nerve diameter of patients with diabetes was found using ultrasonography. We suggest that in patients who are at risk for peripheral neuropathy, ultrasonography is a valuable radiological evaluation technique for the early detection of changes in the median nerve before the development of clinical findings.

Ethics Committee Approval: Ethics committee approval was received for this study from the Ethics Committee of the Bakırköy Education and Reasearch Hospital (2018/113).

Informed Consent: Written informed consent was obtained from all the patients who participated in this study.

Peer-review: Externally peer-reviewed.

Author Contributions: Concept - E.Ç., S.Ç.O.; Design - E.Ç., S.Ç.O.; Supervision - E.Ç., S.Ç.O.; Resource - E.Ç.; Materials S.Ç.O.; Data Collection and/or Processing - S.Ç.O.; Analysis and/ or Interpretation - E.Ç., S.Ç.O.; Literature Search - E.Ç.; Writing - E.Ç.; Critical Reviews - S.Ç.O.

Conflict of Interest: No conflict of interest was declared by the authors.

Financial Disclosure: The authors declared that this study has received no financial support.

\section{References}

1. Rota E, Morelli N. Entrapment neuropathies in diabetes mellitus. World J. Diabetes 2016; 7: 342-53. [CrossRef]

2. Smith LL, Burnet SP, McNeil JD. Musculoskeletal manifestations of diabetes mellitus. Br Jr Sports Med 2003; 37: 30-5. [CrossRef]
3. Arkkila PE, Gautier JF. Musculoskeletal disorders in diabetes mellitus: An update. Best Pract Res Clin Rheumatol 2003; 17: 945-70. [CrossRef]

4. Fornage BD, Rifkin MD. Ultrasound examination of the hand. Radiology 1986; 160: 853-4. [CrossRef]

5. Fornage BD, Rifkin MD. Ultrasound examination of the hand and foot. Radiol Clin North Am 1988; 26: 109-29.

6. Lekholm C, Sundkvist G, Lundborg G, Dahlin L. The diabetic hand--complications of diabetes. Lakartidningen 2001; 98: 306-12.

7. Chammas M. Carpal tunnel syndrome. Chir Main 2014; 33: 75-94. [CrossRef]

8. Bahrmann A, Zieschang T, Neumann T, Hein G, Oster P. Carpal tunnel syndrome in diabetes mellitus. Med Klin (Munich) 2010; 105: 150-4. [CrossRef]

9. Ozkul Y, Sabuncu T, Kocabey Y, Nazligul Y. Outcomes of carpal tunnel release in diabetic and non-diabetic patients. Acta Neurol Scand 2002; 106: 168-72. [CrossRef]

10. Chammas M, Bousquet P, Renard E, Poirier JL, Jaffiol C, Allieu Y. Dupuytren's disease, carpal tunnel syndrome, trigger finger, and diabetes mellitus. J Hand Surg Am. 1995; 20: 109-14. [CrossRef]

11. Jayaraman S, Naidich TP. The carpal tunnel: ultrasound display of normal imaging anatomy and pathology. Neuroimaging Clin N Am 2004; 14: viiii103-13.

12. Koenig RW, Pedro MT, Heinen CP, Schmidt T, Richter HP, Antoniadis G, et al. High-resolution ultrasonography in evaluating peripheral nerve entrapment and trauma. Neurosurg Focus 2009; 26: E13. [CrossRef]

13. Duncan I, Sullivan P, Lomas F. Sonography in the diagnosis of carpal tunnel syndrome. AJR Am Journal of Roentgenol 1999; 173: 681-4. [CrossRef]

14. Nakamichi K, Tachibana S. Ultrasonographic measurement of median nerve cross-sectional area in idiopathic carpal tunnel syndrome: Diagnostic accuracy. Muscle Nerve 2002; 26: 798803. [CrossRef]

15. Yesildag A, Kutluhan S, Sengul N, Koyuncuoglu HR, Oyar O, Guler K, et al. The role of ultrasonographic measurements of the median nerve in the diagnosis of carpal tunnel syndrome. Clin Radiol 2004; 59: 910-5. [CrossRef]

16. Kotevoglu N, Gulbahce-Saglam S. Ultrasound imaging in the diagnosis of carpal tunnel syndrome and its relevance to clinical evaluation. Joint Bone Spine 2005; 72: 142-5. [CrossRef]

17. Wiesler ER, Chloros GD, Cartwright MS, Smith BP, Rushing J, Walker FO. The use of diagnostic ultrasound in carpal tunnel syndrome. J Hand Surg Am 2006; 31: 726-32. [CrossRef]

18. Kwon BC, Jung KI, Baek GH. Comparison of sonography and electrodiagnostic testing in the diagnosis of carpal tunnel syndrome. J Hand Surg Am 2008; 33: 65-71. [CrossRef] 